UDC 678.6-1;678.027.7

\author{
V.I. Sytar, I.M. Kuzyayev, K.M. Sukhyy, O.S. Kabat, E.A. Belyanovskaya
}

\title{
INFLUENCE OF THE NATURE AND CONCENTRATION OF POROGENS ON THE STRUCTURE AND PROPERTIES OF PHENYLONE
}

\author{
Ukrainian State University of Chemical Technology, Dnipro, Ukraine
}

\begin{abstract}
Experimental and theoretical studies in the field of development and modernization of gas-filled polymeric materials were analyzed. The foamed material structure was shown to be dependent on the nature and concentration of porogens. The choice of phenylone as a polymer matrix and magnesium carbonate as a gasifier was substantiated to develop heatproof foamed polymer compositions with increased strength properties. Thermal gravimetric analysis of the substances formed at the temperatures of phenylone transitions to the state of viscous flow with emission of gaseous products was performed. According to experimental results, magnesium carbonate $\left(\mathrm{MgCO}_{3}\right)$ was chosen as a porogen that is decomposed during heating with the formation of carbon dioxide and magnesium oxide. The most intense gas production process proceeded at $590 \mathrm{~K}$ during $15-20 \mathrm{~min}$. The high values of melt viscosity of aromatic polyamide phenylone considerably blocked pore formation in the bulk of a polymer. In order to decrease the viscosity of the melt composition, it was doped with 2-3 wt.\% of oligodimethylsiloxane. The results of thermomechanical study revealed that magnesium oxide, which was formed when magnesium carbonate was decomposed, have a thermostabilizing effect on the polymer, which resulted in an increase in the glass transition temperature of phenylone. It was shown that the main characteristics of the developed materials (density, thermal conductivity, and specific heat capacity) were strongly affected by porogen concentration. The study of the surface morphology of the samples exhibited a highly dispersed structure in the polymer volume with pore size close to $100-300 \mu \mathrm{m}$. Comparative analysis of foamed phenylone and commercial foamed plastics revealed that the maximal operational temperature was about $653 \mathrm{~K}$ for the materials developed in this work, whereas this parameter was close to $423 \mathrm{~K}$ for known foamed plastics. The developed material can be recommended to use for heat insulation in aircraft and aerospace industries.
\end{abstract}

Keywords: gas-filled polymeric materials, phenylone, thermophysical characteristics, gasifier, magnesium carbonate.

DOI: $10.32434 / 0321-4095-2019-127-6-213-220$

\section{Introduction}

Gas-filled plastics are two-phase systems consisting of polymeric matrix and uniformly dispersed gas phase. Such a plastic structure has an infinitesimal mass and shows high heat-insulating and soundproof characteristics.

Specific features of gas-filled plastics determine the technical trends and economic efficiency of their application in various industries. Due to low density, high thermal and acoustic properties, high specific strength, and a number of other valuable technological and operational properties, foam plastics are widely used in up-to-date industry [1-3].
Properties of gas-filled polymeric materials depend on a number of factors, among which the characteristics of polymer matrices and substances used to foam the polymers (i.e. foaming agents) should be firstly mentioned for the cases when the foamed composites are prepared by chemical methods. Additionally, the quality of the finished products from gas-filled plastics is affected by the way of products fabrication (extrusion, injection moulding, pressing, etc.) and the parameters of the process (temperature, viscosity, draw speed of extrudate, etc.).

However, most of the known gas-filled plastics

(C) V.I. Sytar, I.M. Kuzyayev, K.M. Sukhyy, O.S. Kabat, E.A. Belyanovskaya, 2019

Influence of the nature and concentration of porogens on the structure and properties of phenylone 
demonstrate some disadvantages. Therefore, their application is significantly limited by reduced fire resistance, heat resistance and temperature resistance at operating temperatures above $473 \mathrm{~K}$. Moreover, irreversible deformations occur to develop foam in plastics under prolonged static loads. These processes result in changes of the geometric sizes of the articles made of foam plastics.

One of the main tasks in this area is the precise control of the powder formation process in order to obtain pores in the form of gas bubbles (blisters) of a given structure and concentration. For several decades, scientists from many countries have carried out numerous experimental and theoretical studies.

The works by Han and Villamizar [4,5] can be mentioned as a one from the first publications on this subject that demonstrated a systemic approach to the problem concerned. They conducted a series of experimental studies on the visualization of the dynamic behavior of bubbles. Several types of polymer matrices, namely, polyethylene of high pressure (AMOSO 48-460U2), polystyrene (STYRON 678), and polycarbonate were investigated. As the initiator of the formation of pores (porogens), the following substances were investigated: sodium bicarbonate $\left(\mathrm{NaHCO}_{3}\right)$, which forms $\mathrm{CO}_{2}$ gas and water vapor; hydrazide (Celogen $\mathrm{CB}$ ), which forms $\mathrm{N}_{2}$; and 5-phenyltetrazole (Expandex 5PT), which generates nitrogen. At the same time, the decomposition temperatures for $\mathrm{NaHCO}_{3}$ and Celogen $\mathrm{CB}$ are 373-413 $\mathrm{K}$ and $460-473 \mathrm{~K}$, respectively.

It was established that the behavior of bubbles corresponds to a certain critical pressure. The critical pressure was found to decrease with increasing the temperature of the melt and to increase with increasing the concentration of porogens.

Experiments were carried out both under isothermal conditions and under temperature gradient [5]. Data presented in this work indicated that an increase in the size of bubbles could be practically unlimited when a constant temperature was maintained. As the solidification of the material proceeded, the size of the bubble underwent intense changes during $50 \mathrm{~s}$, then the growth rate of the radius slowed down and the growth stopped during one minute.

It was shown [6] that the structure of the foamed polyolefins varied with the extrusion modes, namely, the melt temperature; the speed of rotation of the worm; and the drawing speed of extrudate. In this case, sodium hydrogen carbonate and citric acid were used as foaming agents. According to the obtained results, the melt temperature significantly affected the character of the change in the size of the bubbles in the production of the foamed polymeric materials. Moreover, the temperature and the size of the bubbles appear to increase simultaneously.

If there is a need for a finely dispersed structure, it is necessary to conduct the process at low temperatures. Additionally, other parameters, including the speed of the worm rotation and the drawing rate the extrudate, which in turn, affect the temperature, ought also to take into account.

The structure and quality of the foamed materials are strongly affected by the choice of the foaming agent in the polymer matrix and the concentration of the porogen. According to ref. [7], the pore sizes and their morphology depend on the content of the porogen in the initial polymer composition. As stated by the microphotographs, the different contents of the foaming agent in the initial composition strongly affect the structure of the resulting foamed polymer. In this case, the surface of the foamed polyethylene terephthalate with a content of a porogen of $0.3 \mathrm{wt} . \%$ in the initial composition exhibits reduced size and number of pores as compared to the material containing $0.5 \mathrm{wt} . \%$ of porogen. The structure is known to affect the properties of the obtained products. Therefore, physical and mechanical characteristics of the foamed polymer with a content of porogen of $0.3 \mathrm{wt} . \%$ in the initial composition exceed by $10-15 \%$ the materials containing $0.5 \mathrm{wt} . \%$.

The structure of pores is affected by the presence of a dispersed filler in the foamed polymer composition [8]. SEM microphotograph of the surface of the initial foamed polymer and that filled with 4 wt.\% of dispersed clay (C20A) showed that the pores in the foamed polymer filled with dispersed filler have lesser size and more stable morphology than those of the unfilled polymer. This feature is explained by the fact that the filler particles are a barrier, which prevents free release of the gas from the polymer melt during the process of poreformation. As a result, the size of the bubbles decreases, their number increases, and a similar structure is formed.

One of the most important factors that affected the pore size and structure is the pressure in the polymer-bubble system. The effect of the saturation pressure on the system of poly ( $\varepsilon$-caprolactone) (PCL) $-\mathrm{CO}_{2}$ bubbles was investigated [9]. According to the obtained results, different morphology is observed for different pressure values. At low values of pressure, closed cells are formed. When the saturation pressure is sufficiently high (in this case at $\mathrm{P}_{2}=10 \mathrm{MPa}$ ), the boundaries of the cells are not 
Basic characteristics of some well-known foamed polymers

\begin{tabular}{l|c|c|c|c|c}
\hline \multicolumn{1}{c|}{ Characteristics } & $\begin{array}{c}\text { Expanded } \\
\text { polyethylene } \\
(\mathrm{PE})\end{array}$ & $\begin{array}{c}\text { Polystyrene } \\
\text { foam } \\
(\mathrm{PPS}-1)\end{array}$ & $\begin{array}{c}\text { Polyvinyl } \\
\text { chloride } \\
\text { foam (PV-1) }\end{array}$ & $\begin{array}{c}\text { Foamed } \\
\text { polyurethane } \\
\text { (PPU-308) }\end{array}$ & $\begin{array}{c}\text { Foamed } \\
\text { epoxide } \\
\text { (PE-8) }\end{array}$ \\
\hline Density, $\mathrm{kg} / \mathrm{m}^{3}$ & 600 & 400 & 400 & 300 & 290 \\
\hline Compression strain & 3.5 & 5.0 & 5.0 & 3.0 & 2.0 \\
\hline Maximal allowable temperature, $\mathrm{K}$ & 353 & 338 & 343 & 393 & 373 \\
\hline Minimal allowable temperature, $\mathrm{K}$ & 213 & 213 & 203 & 213 & 213 \\
\hline Heat conductivity, $\mathrm{W} / \mathrm{m} \cdot \mathrm{K})$ & 0.029 & 0.027 & 0.035 & 0.02 & 0.029 \\
\hline
\end{tabular}

clearly visible, that is, the cells are opened. In order to obtain foamed materials with a predetermined structure, the process should be performed with strict conformity to the operational regimes and characteristics of the material.

To summarize, some characteristics of the most widely used foamed polymer materials are given in Table 1 [1].

\section{Experimental}

The material density was determined by the method of hydrostatic weighing according to ISO 1183-1. The Vicat softening temperature was measured according to ISO 1183-1 on the FWV$633 / 10$.

The heat capacity of materials was determined by the method of measuring the heat flow, which absorbs the sample at monotonous heating in accordance with the State Standard 23630.1-79. The thermal conductivity of materials was established by the method of measuring the thermal resistance during monotonous heating according to the State Standard 23630.2-79.

The resistance to the temperature of the polymeric composite materials and the initial polymers were determined by the method of thermogravimetric analysis (TGA) according with ISO-11358 by using a derivatograph Q1500D.

In order to improve the performance of the foamed polymers, the phenylone aromatic polyamide, which is an analogue of the well-known materials such as kevlar and nomex, was chosen as a polymer base. It exceeds the majority of industrial thermoplastic polymers in a complex of physicalmechanical and thermophysical properties. The temperature of the treatment of the products made from it reaches $563 \mathrm{~K}$, and the strength properties are 220-240 MPa [10].

Magnesium carbonate was chosen as a porogen. It decomposes with the release of carbon dioxide forming pores in the volume of polymer at a softening temperature of phenylone (about $613 \mathrm{~K}$ ). However, another product of decomposition is magnesium oxide, which is a thermal stabilizer. Moreover, its presence contributes to improving the heat resistance of phenylone.

To determine the influence of the pore formers on the structure and properties of phenylone, thermal stability, heat resistance and thermophysical characteristics, i.e., the coefficients of heat and thermal conductivity and density, were studied. Additionally, the viscosity of composites was studied depending on the modifiers type.

For the experimental study on the foamformation in the compositions, the samples were manufactured by compression pressing. To remove the moisture that is the agent providing the destruction of phenylone, the press material was predried at $453 \mathrm{~K}$ for 40 minutes. Pressing of the samples was carried out at the temperature of $603 \mathrm{~K}$ and the specific pressure of $40 \mathrm{MPa}$ followed by cooling to the temperature of $470 \mathrm{~K}$. The samples were expanded in the form at a temperature of $613 \mathrm{~K}$ for 15-20 minutes.

\section{Results and discussion}

To form a foamed plastic based on phenylone, porogens were used. One of the methods to achieve this effect is the introduction of substances into the composition, which are decomposed during heating with the release of gaseous products forming pores in the polymer when it passes into a viscous-fluid state.

For this purpose, the decomposition of compounds associated with the release of gas-forming products during the transition of phenylone into a viscous-fluid state was studied by TGA method. Magnesium carbonate $\left(\mathrm{MgCO}_{3}\right)$, ammonium chloride $\left(\mathrm{NH}_{4} \mathrm{Cl}\right)$ and polyvinyl alcohol (PVA) were chosen as gasifiers. The introduction of $\mathrm{MgCO}_{3}$ was the most efficient and ensured coincidence between the decomposition temperature and the temperature of the phenylone transition into a viscous-fluid state.

Figure 1 shows the data of the thermogravimetric analysis of the above-mentioned compounds. The obtained results indicate that the selected substances are rapidly decomposed in the temperature range of 573-613 K. Magnesium 
carbonate decomposes with the release of carbon dioxide $\mathrm{CO}_{2}$ and magnesium oxide $\mathrm{MgO}$, and ammonium chloride resolves into ammonia and hydrogen chloride. Polyvinyl alcohol decomposes into acetic aldehyde and carbon dioxide.

It should be noted that the decomposition temperature of ammonium chloride is somewhat lower than the transition of phenylone to the viscousfluid state. In this process, harmful substances are released to environment during the decomposition. The decomposition of polyvinyl alcohol proceeds in a sufficiently wide range of temperature that does not ensure the desired effect of the foam-formation.

Based on the data of the thermogravimetric analysis, magnesium carbonate was selected as a porogen for further investigation.

In order to determine the duration of full decomposition of $\mathrm{MgCO}_{3}$ corresponded to the

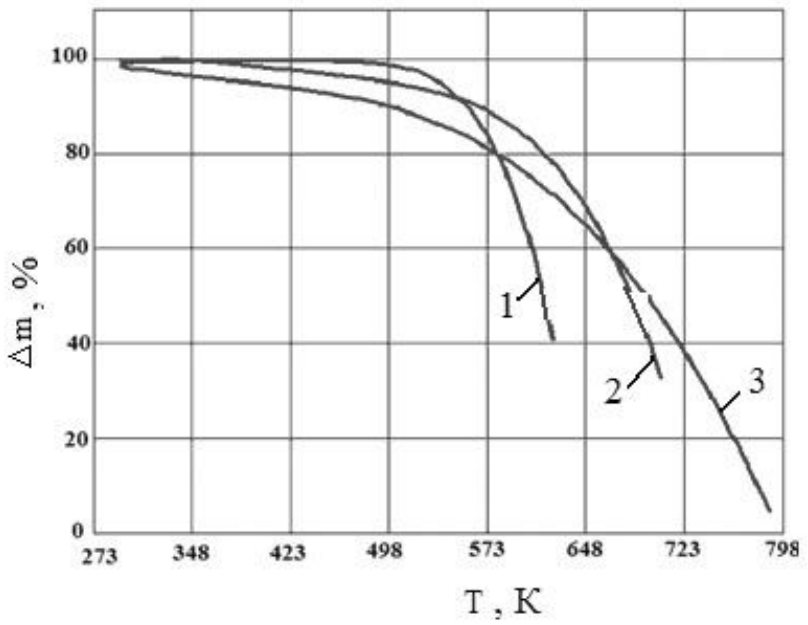

Fig. 1. Variation of porogen mass with temperature: $1-\mathrm{NH}_{4} \mathrm{Cl} ; 2-\mathrm{MgCO}_{3} ; 3-\mathrm{PVA}$

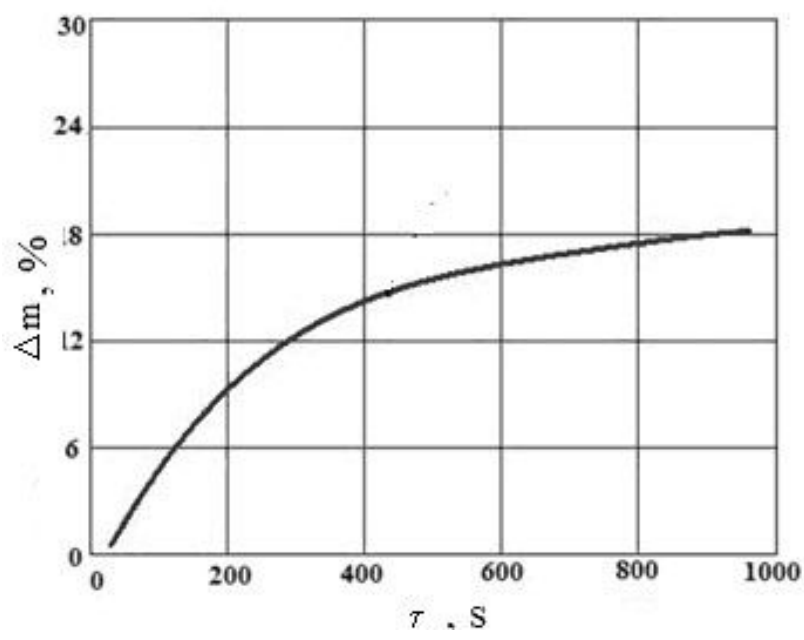

Fig. 2. $\mathrm{MgCO}_{3}$ mass losses versus duration of the heat treatment at $590 \mathrm{~K}$ maximal release of the gaseous components, the kinetics of $\mathrm{MgCO}_{3}$ decomposition was studied at the temperature of $590 \mathrm{~K}$. Practically complete decomposition of $\mathrm{MgCO}_{3}$ is achieved within 15-20 minutes (Fig. 2).

Numerous studies showed that an increase in the concentration of $\mathrm{MgCO}_{3}$ provides an enhanced thermostabilizing effect of the released magnesium oxide on the phenylone, which further improves its heat resistance and extended the range of the operating temperatures (Fig. 3).

The study of the main characteristics of the developed materials showed that their density $(\rho)$ and thermal conductivity $(\lambda)$ are closely related to the concentration of porogen (Figs. 4 and 5). This means that a decrease in the density and an increase in the thermal conductivity of the materials are observed as the concentration of $\mathrm{MgCO}_{3}$ increases. One of the main characteristics of foam

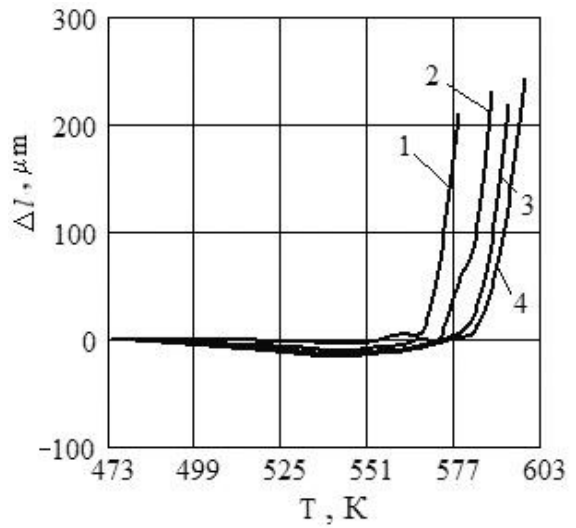

Fig. 3. Deformation $\Delta \mathrm{l}$ of expanded samples variation with temperature: 1 - phenylone $\mathrm{C} 2+2 \%$ PMS; 2 - phenylone $\mathrm{C} 2+2 \% \mathrm{PMS}+5 \% \mathrm{MgCO}_{3} ; 3-$ phenylone $\mathrm{C} 2+2 \%$

$\mathrm{PMS}+10 \% \mathrm{MgCO}_{3} ; 4-$ phenylone $\mathrm{C} 2+2 \% \mathrm{PMS}+15 \% \mathrm{MgCO}_{3}$

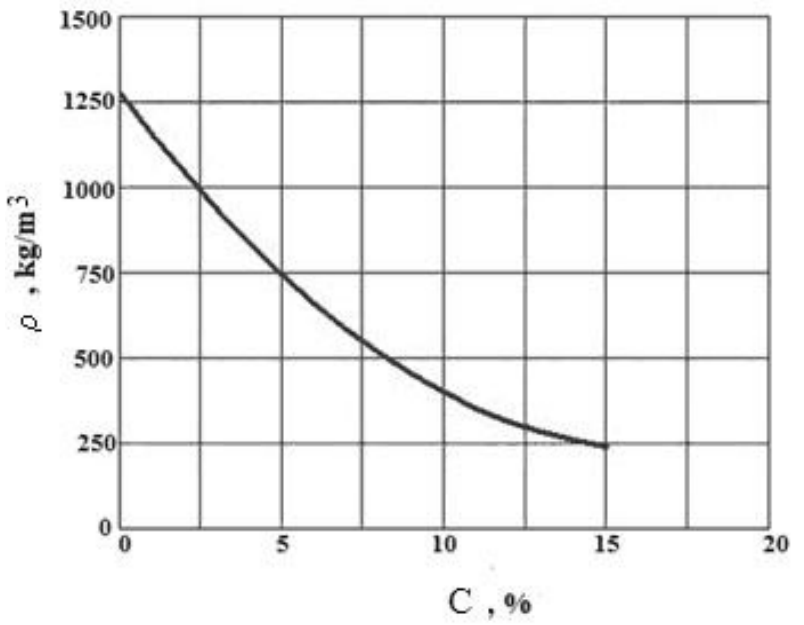

Fig. 4. Packing density versus concentration of $\mathrm{MgCO}_{3}$ 
materials is their thermal conductivity, because of most of them are used as heat insulation. As the temperature is increased, the thermal conductivity of polymer composite material not practically change, and its values being stable up to $553 \mathrm{~K}$ (Fig. 5).

This dependence can be explained by simultaneous increase of both the total area of pores and transfer of heat due to increased concentration of porogen $\left(\mathrm{MgCO}_{3}\right)$.

Thus, the study of the heat capacity of the

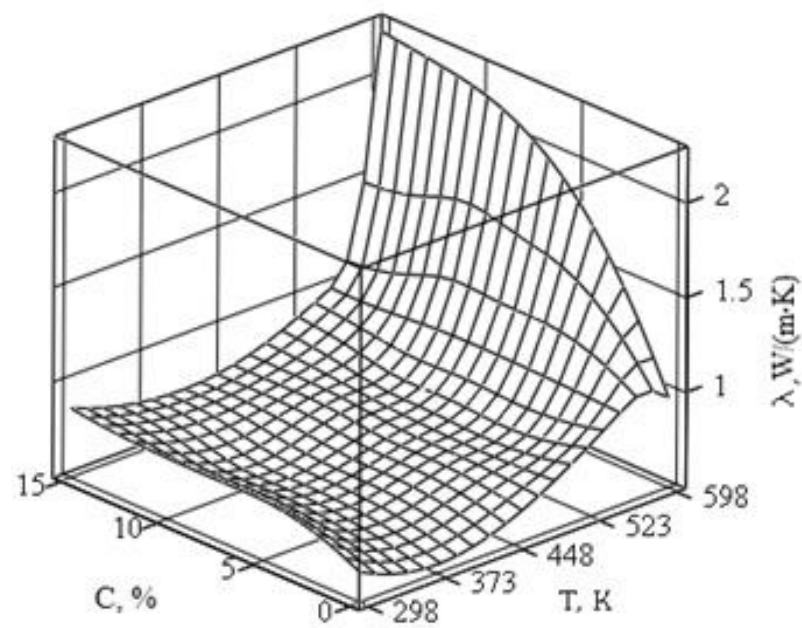

Fig. 5. Variation of heat conductivity factor of composite material with temperature and porogen concentration:

1 - phenylone $\mathrm{C} 2+2 \%$ PMS; 2 - phenylone $\mathrm{C} 2+2 \%$ $\mathrm{PMS}+5 \% \mathrm{MgCO}_{3} ; 3$ - phenylone $\mathrm{C} 2+2 \% \mathrm{PMS}+10 \% \mathrm{MgCO}_{3}$; 4 - phenylone $\mathrm{C} 2+2 \% \mathrm{PMS}+15 \% \mathrm{MgCO}_{3}$

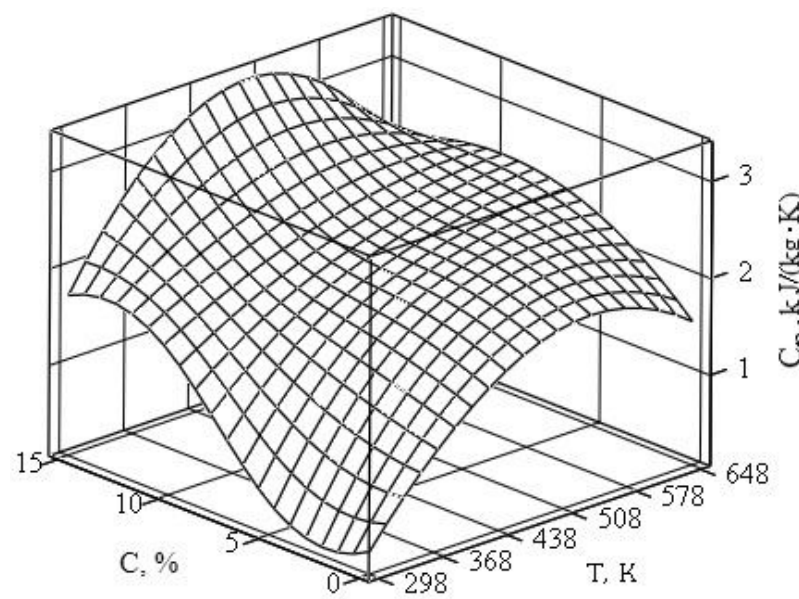

Fig. 6. Variation of specific heat with temperature and concentration of porogen $\mathrm{MgCO}_{3}$ :

1 - phenylone $\mathrm{C} 2+2 \% \mathrm{PMS}$;

2 - phenylone $\mathrm{C} 2+2 \% \mathrm{PMS}+5 \% \mathrm{MgCO}_{3}$;

3 - phenylone $\mathrm{C} 2+2 \% \mathrm{PMS}+10 \% \mathrm{MgCO}_{3}$;

4 - phenylone $\mathrm{C} 2+2 \% \mathrm{PMS}+15 \% \mathrm{MgCO}_{3}$ foamed materials based on phenylone is of significant interest. The results of the measurement of the specific heat of the polymeric composite materials (Fig. 6) showed that increasing temperature results in an increase in the value of specific heat, and its maximum values is close to the glass transition temperature of the polymeric composite materials $(548 \mathrm{~K})$. In addition, the specific heat depends on the concentration of $\mathrm{MgCO}_{3}$ : the specific heat increases with an increase in the concentration of $\mathrm{MgCO}_{3}$ in polymeric composite materials, which is the consequence of an increase in the absorbing capacity of the material.

The aromatic polyamide phenylone has a high viscosity of the melt, which creates a significant barrier to the pore-formation in the bulk of the polymer. To improve the viscosity characteristics, the phenylone was modified by oligodimetilsiloxane (PMS), hexadimethylsilosan (GMDSS) and diphenylsilanediol (DFSDO). The introduction of silicone-organic additives to the composition provides a significant decrease in the viscosity of polymer melt $[11,12]$. At a temperature of $613 \mathrm{~K}$ and a shearing stress of $2.0 \mathrm{MPa}$, the melt viscosity decreases by an order of magnitude.

The viscosity of the obtained polymeric composites was determined by viscosimetric method (Fig. 7).

According to the results of the experiment, the introduction of PMS into phenylon $\mathrm{C} 2$ allows reducing the viscosity of the melt of polymeric

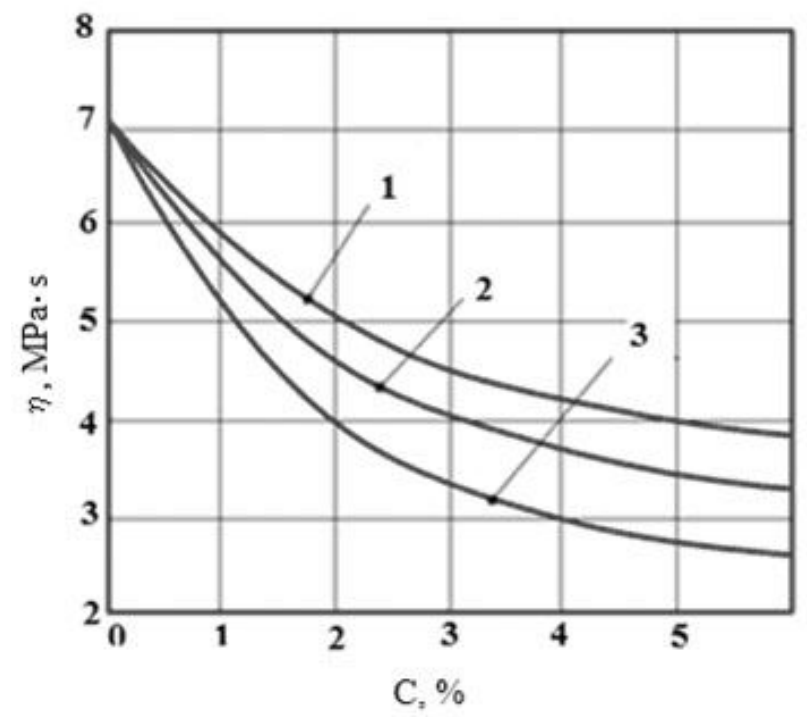

Fig. 7. Dependence of the melt viscosity of polymeric systems on the modifier concentration in phenylone:

1 - phenylone $\mathrm{C} 2+2 \%$ GMDSS;

2 - phenylone $\mathrm{C} 2+2 \%$ GMDSS;

3 - phenylone $\mathrm{C} 2+2 \%$ PMS 


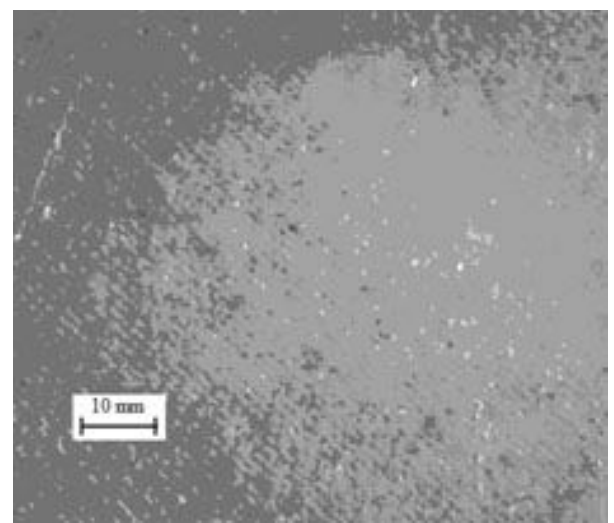

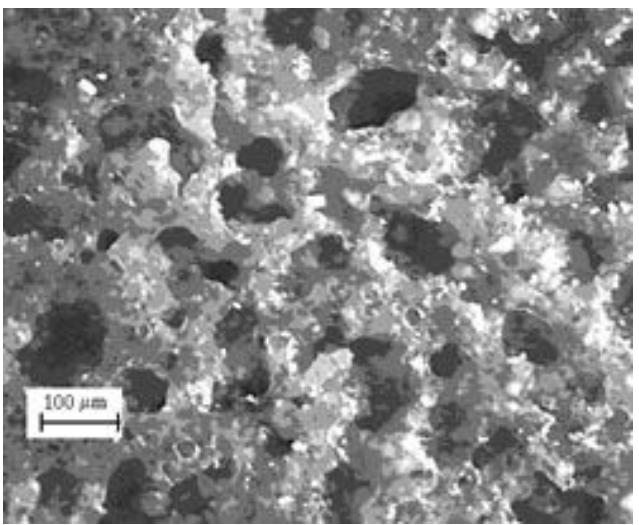

b

Fig. 8. Surface morphology of composition based on phenylone $\mathrm{C} 2+2 \% \mathrm{PMS}+10 \% \mathrm{MgCO}_{3}$ : $\mathrm{a}$ - before expansion; $\mathrm{b}$ - after heat treatment at $590 \mathrm{~K}$

composite materials. An intensive decrease in viscosity is observed in composites containing PMS up to $2 \%$. A further increase in the content of the modifier does not cause a significant reduction of viscosity, while the incompatibility of the components and the visible phase separation occur, which leads to a decrease in the mechanical properties.

For the foamed compositions based on phenylone, an optical study of their surface was conducted, the presence of a finely porous structure in the bulk of the polymer was observed (Fig. 8). The sizes of the pores were about $100-300 \mu \mathrm{m}$.

Key characteristics of the most optimal foamed phenylone are given in Table 2. Comparison of the data presented Tables 1 and 2 shows that most characteristics of the foamed phenylone exceed those typical of common plastic foams.

Table 2

\section{Characteristics of foamed phenylone}

\begin{tabular}{l|c}
\hline \multicolumn{1}{c|}{ Characteristic } & Value \\
\hline Density, $\mathrm{kg} / \mathrm{m}^{3}$ & 230 \\
\hline Compression strain, $\mathrm{MPa}$ & 6 \\
\hline Maximal allowable temperature, $\mathrm{K}$ & 573 \\
\hline Minimal allowable temperature, $\mathrm{K}$ & 193 \\
\hline Heat conductivity, $\mathrm{W} /(\mathrm{m} \cdot \mathrm{K})$ & 0.03 \\
\hline
\end{tabular}

The maximum allowable operating temperature for most known foamed polymers is about $373 \mathrm{~K}$, while it reaches $573 \mathrm{~K}$ in case of the foamed phenylone. The minimum allowable operating temperature for known foamed polymers is about $213 \mathrm{~K}$, whereas it is $193 \mathrm{~K}$ for the foamed phenylone. A compressive strain reaches $6.0 \mathrm{MPa}$ for the developed polymeric composite materials, this is an excellent result as compared with the values of 3$5 \mathrm{MPa}$ that are typical of other foamed polymers.

\section{Conclusions}

1. The process of pore-formation in polymers is determined by the concentration of porogens, the conditions of the implementation of the process and the structure and properties of the polymer. Changing the conditions of the foaming process can affect the size and number of formed pores, thus the properties of the foamed plastics being regulated.

2. In order to prepare plastic foams, it is expedient to use phenylone $\mathrm{C} 2$ aromatic polyamide as a polymeric base.

3. In order to reduce the viscosity of the phenylone melt, it is appropriate to introduce siliconorganic modifiers into (2-3 wt.\%).

4. To realize the process of pore-formation in phenylone, magnesium carbonate should be included in its composition. At the transition temperatures of the phenylone in the viscous-fluid state, magnesium carbonate decomposes with the release of carbon dioxide, which expanded the polymer.

5. According to the obtained results, some optimal concentrations of porogens were selected, which allow fabricating plastic foams based on phenylone with an enhanced thermophysical and mechanical properties. These materials can be recommended for manufacturing application as a thermal insulation in aircraft and aerospace industries.

\section{REFERENCES}

1. Kabat O., Sytar V., Sukhyy K. Antifrictional polymer composites based on aromatic polyamide and carbon black // Chem. Chem. Technol. - 2018. - Vol.12. - No. 3. - P.326-330.

2. Obi B.E. Overview of applications of polymeric foams // Polymeric Foams Structure-Property-Performance. Netherlands: Elsevier, 2018. - P.3-14. 
3. Microcellular foamed aromatic polyamides (aramids). Structure, thermal and mechanical properties / Pascual B.S., Trigo-Lopea M., Ramos C., Sanz M.T., Pablos J.L., Garcia F.C., Ruiz J.A.R., Garcia J.M. // Eur. Polym. J. - 2019. - Vol.110. P.9-13.

4. Han C.D., Villamizar C.A. Studies on structural foam processing I. The rheology of foam extrusion // Polym. Eng. Sci. - 1978. - Vol.18. - No. 9. - P.687-698.

5. Villamizar C.A., Han C.D. Studies on structural foam processing II. Bubble dynamics in foam injection molding // Polym. Eng. Sci. - 1978. - Vol.18. - No. 9. - P.699-710.

6. Growth of gas bubbles in the foam extrusion process / C.H. Lee, K.-J. Lee, H.G. Jeong, S.W. Kim // Adv. Polym. Technol. - 2000. - Vol.19. - No. 2. - P.97-112.

7. Theoretical and experimental study of foaming process with chain extended recycled PET / I. Coccorullo, L. Di Maio, S. Montesano, L. Incarnato // Express Polym. Lett. - 2009. Vol.3. - No. 2. - P.84-96.

8. Foaming behavior of high-melt strength polypropylene/ clay nanocomposites / Bhattacharya S., Gupta R.K., Jollands M., Bhattacharya S.N. // Polym. Eng. Sci. - 2009. - Vol.49. - No. 10. - P.2070-2084

9. Validated modeling growth, impingement and retraction to predict cell-opening in thermoplastic foaming / Tammaro D., D’Avino G., Di Maio E., Pasquino R., Villone M.M., Gonzales D., Groombridge M., Grizzuti N., Maffettone P.L. // Chem. Eng. J. - 2016. - Vol.287. - P.492-502.

10. Сытар В.И. Изучение взаимосвязи свойств и строения сополимеров на основе ароматических полиамидов // Вопросы химии и хим. технологии. - 2004. - № 3. - С.130132.

11. Ситар В.І., Кузяєв І.М., Данилін Д.С. Дослідження реології розплаву модифікованих систем на основі фенілону // Вопросы химии и хим. технологии. -2003 . - № 2. C.104-107.

12. Role of ionene in composition of porous structure of template-synthesized silicas / Berezovska I.S., Yanishpolskii V.V., Tertykh V.A., Burmistr M.V., Sukhyy K.M. // J. Therm. Anal. Cal. - 2006. - Vol.86. - No. 1. - P.93-96.

Received 07.05.2019

\section{ВПЛИВ ПРИРОДИ ТА КОНЦЕНТРАЦІЇ ПОРОУТВОРЮВАЧІВ НА СТРУКТУРУ І ВЛАСТИВОСТІ ФЕНІЛОНУ}

\section{B.I. Ситар, I.М. Кузяев, К.М. Сухий, О.С. Кабат, О.А. Беляновська}

Розглянуті результати експериментальних й теоретичних досліджень в галузі розробки та удосконалення газонаповнених полімерних матеріалів. Показано, що структура спіненого матеріалу залежить від природи та концентрації пороутворювача. Обгрунтовано вибір фенілону, як полімерної матриці для створення теплостійких спінених полімерних композицій. Виконано термогравіметричний аналіз речовин, що розкладаються при температурах переходу фенілону у в'язкоплинний стан з виділенням газоподібних продуктів. За результатами досліджень в якості пороутворювача для фенілону обрано магній карбонат $\left(\mathrm{MgCO}_{3}\right)$, який в процесі нагрівання розкладається з виділенням карбон діоксиду та магній оксиду. Процес газоутворення найбільш інтенсивно протікає при температурі 590 К протягом 15-20 хвилин. Ароматичний поліамід фенілон має високу в'язкість розплаву, що створює суттєві перешкоди для пороутворення в масі полімеру. 3 метою зниження в язкості розилаву до його складу додавали до 2-3 мас.\% олігодиметилсилоксану. Проведені термомеханічні дослідження вказують на те, що магній оксид, який утворюється при розкладанні магній карбонату, здійснює термостабілізуючу дію, у результаті чого підвищується температура склування фенілону. Показано, що основні характеристики розроблених матеріалів (густина, теплопровідність і теплоємність) знаходяться в тісній залежності від концентрації спінюючого агенту. Вивчення морфології поверхні зразків показало на присутність в об 'ємі полімеру дрібнодисперсної структури з розмірами пор близько 100-300 мкм. Порівняльний аналіз спіненого фенілону з промисловими пінопластами показав, що максимальна температур експлуатації розробленого матеріалу складає близько $653 \mathrm{~K}$, на відміну від відомих пінопластів, для яких значення цього показника становить близько $423 \mathrm{~K}$. Розроблені матеріали можуть бути рекомендовані для застосування в якості теплоізоляції в авіаційній та аерокосмічній промисловості.

Ключові слова: газонаповнені полімерні матеріали, фенілон, теплофізичні характеристики, газоутворювач, магній карбонат. 


\section{INFLUENCE OF THE NATURE AND CONCENTRATION OF POROGENS ON THE STRUCTURE AND PROPERTIES OF PHENYLONE}

\section{V.I. Sytar, I.M. Kuzyayev, K.M. Sukhyy, O.S. Kabat, E.A. Belyanovskaya}

Ukrainian State University of Chemical Technology, Dnipro, Ukraine

* e-mail: v.sytar@ua.fm

Experimental and theoretical studies in the field of development and modernization of gas-filled polymeric materials were analyzed. The foamed material structure was shown to be dependent on the nature and concentration of porogens. The choice of phenylone as a polymer matrix and magnesium carbonate as a gasifier was substantiated to develop heatproof foamed polymer compositions with increased strength properties. Thermal gravimetric analysis of the substances formed at the temperatures of phenylone transitions to the state of viscous flow with emission of gaseous products was performed. According to experimental results, magnesium carbonate $\left(\mathrm{MgCO}_{3}\right)$ was chosen as a porogen that is decomposed during heating with the formation of carbon dioxide and magnesium oxide. The most intense gas production process proceeded at $590 \mathrm{~K}$ during $15-$ $20 \mathrm{~min}$. The high values of melt viscosity of aromatic polyamide phenylone considerably blocked pore formation in the bulk of a polymer. In order to decrease the viscosity of the melt composition, it was doped with 2-3 wt.\% of oligodimethylsiloxane. The results of thermomechanical study revealed that magnesium oxide, which was formed when magnesium carbonate was decomposed, have a thermostabilizing effect on the polymer, which resulted in an increase in the glass transition temperature of phenylone. It was shown that the main characteristics of the developed materials (density, thermal conductivity, and specific heat capacity) were strongly affected by porogen concentration. The study of the surface morphology of the samples exhibited a highly dispersed structure in the polymer volume with pore size close to 100-300 $\mu \mathrm{m}$. Comparative analysis of foamed phenylone and commercial foamed plastics revealed that the maximal operational temperature was about $653 \mathrm{~K}$ for the materials developed in this work, whereas this parameter was close to $423 \mathrm{~K}$ for known foamed plastics. The developed material can be recommended to use for heat insulation in aircraft and aerospace industries.

Keywords: gas-filled polymeric materials; phenylone; thermophysical characteristics; gasifier; magnesium carbonate.

\section{REFERENCES}

1. Kabat O., Sytar V., Sukhyy K. Antifrictional polymer composites based on aromatic polyamide and carbon black. Chemistry \& Chemical Technology, 2018, vol. 12, pp. 326-330.

2. Obi B.E. Overview of applications of polymeric foams. In: Polymeric foams structure-property-performance. Elsevier, 2018, pp. 3-14.

3. Pascual B.S., Trigo-Lopez M., Ramos C., Sanz M.T., Pablos J.L., Garcia F.C., Ruiz J.A.R., Garcia J.M. Microcellular foamed aromatic polyamides (aramids). Structure, thermal and mechanical properties. European Polymer Journal, 2019, vol. 110, pp. 9-13.

4. Han C.D., Villamizar C.A. Studies on structural foam processing I. The rheology of foam extrusion. Polymer Engineering and Science, 1978, vol. 18, pp. 687-698.

5. Villamizar C.A., Han C.D. Studies on structural foam processing II. Bubble dynamics in foam injection molding. Polymer Engineering and Science, 1978, vol. 18, pp. 699-710.

6. Lee C.H., Lee K.J., Jeong H.G., Kim S.W. Growth of gas bubbles in the foam extrusion process. Advances in Polymer Technology, 2000, vol. 19, pp. 97-112.

7. Coccorullo I., Di Maio L., Montesano S., Incarnato L. Theoretical and experimental study of foaming process with chain extended recycled PET. Express Polymer Letters, 2009, vol. 3, no. 2 , pp. $84-96$.

8. Bhattacharya S., Gupta R.K., Jollands M., Bhattacharya S.N. Foaming behavior of high-melt strength polypropylene/clay nanocomposites. Polymer Engineering and Science, 2009, vol. 49, pp. 2070-2084.

9. Tammaro D., D’Avino G., Di Maio E., Pasquino R., Villone M.M., Gonzales D., Groombridge M., Grizzuti N., Maffettone P.L. Validated modeling growth, impingement and retraction to predict cell-opening in thermoplastic foaming. Chemical Engineering Journal, 2016, vol. 287, pp. 492-502.

10. Syitar V.I. Izuchenie vzaimosvyazi svoistv i stroeniya sopolimerov na osnove aromaticheskikh poliamidov [Study of the interrelations between properties and composition of copolymers based on aromatic polyamides]. Voprosy Khimii $i$ Khimicheskoi Tekhnologii, 2004, no. 3, pp. 130-132. (in Russian).

11. Sytar V.I., Kuziaiev I.M., Danylin D.S. Doslidzhenniya reologii rozplavu modyfikovanykh system na osnovi fenilonu [Study of the rheology of the melt of modified systems based on phenylone]. Voprosy Khimii i Khimicheskoi Tekhnologii, 2003, no. 2, pp. 104-107. (in Ukrainian).

12. Berezovska I.S., Yanishpolskii V.V., Tertykh V.A., Burmistr M.V., Sukhyy K.M. Role of ionene in composition of porous structure of template-synthesized silicas. Journal of Thermal Analysis and Calorimetry, 2006, vol. 86, pp. 93-96. 